Intersections

Canadian Journal of Music

Revue canadienne de musique
Intersections

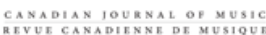

\title{
Addressing Common Parental Concerns about Factors That Could Influence Piano Students' Autonomous Motivation, Diligence, and Performance
}

\section{Gilles Comeau et Veronika Huta}

Volume 35, numéro 1, 2015

URI : https://id.erudit.org/iderudit/1038943ar

DOI : https://doi.org/10.7202/1038943ar

Aller au sommaire du numéro

\section{Éditeur(s)}

Canadian University Music Society / Société de musique des universités canadiennes

\section{ISSN}

1911-0146 (imprimé)

1918-512X (numérique)

Découvrir la revue

Citer cet article

Comeau, G. \& Huta, V. (2015). Addressing Common Parental Concerns about Factors That Could Influence Piano Students' Autonomous Motivation, Diligence, and Performance. Intersections, 35(1), 27-52.

https://doi.org/10.7202/1038943ar

\section{Résumé de l'article}

Nous avons examiné l'effet de diverses décisions que les parents peuvent prendre dans le cadre de l'apprentissage du piano de leurs enfants, par exemple au niveau de l'âge pour commencer cet apprentissage, la méthode d'enseignement, les examens, les cours de groupes, l'assistance aux cours, leur présence active lors des pratiques quotidiennes, et le fait de récompenser ces pratiques. Ces choix ont été mis en corrélation avec diverses variables se rapportant au jeu pianistique de l'enfant, c'est-à-dire à leur motivation personnelle, leur intérêt pour l'interprétation et la créativité, leur intérêt pour l'effort mis dans la pratique, le temps qui y est passé, leur sentiment d'habileté, et leur niveau de réussite aux examens. Nous avons soumis 173 élèves de piano, âgés de 6 à 16 ans, ainsi que leurs parents, à une série de questionnaires. Cette étude a permis de révéler certaines des décisions les plus bénéfiques, telles que commencer les leçons avant l'âge de 7 ans, assister aux cours, et aider aux pratiques quotidiennes.
Copyright @ Canadian University Music Society / Société de musique des universités canadiennes, 2016
Ce document est protégé par la loi sur le droit d'auteur. L’utilisation des services d'Érudit (y compris la reproduction) est assujettie à sa politique d'utilisation que vous pouvez consulter en ligne.

https://apropos.erudit.org/fr/usagers/politique-dutilisation/ 


\title{
ADDRESSING COMMON PARENTAL CONCERNS ABOUT FACTORS THAT COULD INFLUENCE PIANO STUDENTS' AUTONOMOUS MOTIVATION, DILIGENCE, AND PERFORMANCE
}

\author{
Gilles Comeau and Veronika Huta
}

Instrumental music lessons require that parents make a large investment in time and financial resources-parents are involved in transportation to and from music lessons, and they have to pay for lessons, buy a musical instrument, and assume the costs of music books (Dai and Schader 2001). But the role of parents is broader still, as they often influence the age of starting lessons as well as the nature of the lessons, and some are directly involved in home practice (Davidson, Howe, and Sloboda 1995). Studies have suggested that parents are an important environmental factor that affects a child's musical success (Sloboda and Davidson 1996; McPherson and Davidson 2002; Moore, Burland, and Davidson 2003), and the parental influence has been identified as a primary external factor affecting a student's motivation (Creech 2001; Sichivitsa 2007; McPherson 2009).

Our research examined how certain choices regarding piano playing that the parent can influence, and certain parental behaviours with regards to their child's piano playing, correlate with the child's motivation, interest, diligence, and performance at the piano. The choices studied were age of starting lessons, number of years of lessons, method of instruction, whether to take exams, and whether to participate in group lessons; the parental behaviours studied were sitting in on lessons, helping with home practice, and giving rewards for practising. One child variable studied was motivation. In music education, discussions of motivation seek to understand why certain students show a strong interest in music lessons while others do not, why students show different amounts of effort in their pursuit of musical mastery, and why some students persevere while others drop out. The importance of parental influences on musical achievement is well recognized, but their impact on piano students' motivation is not as well documented. We based our assessment of motivation on Ryan and Deci's (2000a, 200ob) self-determination theory. This theory emphasizes the importance of measuring not only degree of motivation but also the source of motivation, which can range from unhealthy external or internal pressures (called controlled motivation) to healthy and genuine internal interest and belief in the activity (called autonomous motivation). Additional child variables with regards to the piano were the child's interest in performance and creativity, interest in effortful practice, time spent practising, feeling of 
competence, and exam performance. The links between the parental variables and child variables in this research address some of the biggest questions that parents have regarding how they might positively support their child's piano learning.

\section{Choices That Parents Can Influence, and Parental BEHAVIOURS}

\section{Age of Starting Lessons}

The question of the most appropriate age to start instrumental lessons is a concern for everyone involved in music education. Pedagogy textbooks frequently discuss age readiness for beginning piano lessons (Bastien 1993; Uszler, Gordon, and McBride-Smith 2000). Some promote an early start at four or five years old (Bigler and Lloyd-Watts 1998; Powell 1988; Shor 1989; Suzuki 1969), arguing that there is a high predisposition for music learning in the preschool years (Hodges 2006). Others recommend waiting until the child has completed at least one year of elementary school before registering them in piano lessons (Bastien 1976) and the majority of teachers still believe that the best age to begin individual music lessons is seven years old or eight years old (Uszler, Gordon, and McBride-Smith 200o). Similarly, age readiness is regularly discussed in parents' guide for successful music lessons (Bellavia 2006; Jonas 1988; Schmidt-Jones 2008; Stein Crease 2006) under topics such as "Ready to Begin" (Kazdan 2002), "At What Age Should a Child Start Lessons?" (Grant 1980), and "When Should I Begin Music Lessons for My Child?" (Cutietta 2003).

There is some research literature on the link between the age at which lessons are started and musical performance. When reviewing keyboard players of historical importance, Lehmann (1997) discovered that most performers from Bach to Rubinstein had started lessons between the ages of four and six. When interviewing twenty-four American concert pianists with international careers, Sosniak (1985) reported that most had started lessons before the age of six. Experimental research (Moore, Burland, and Davidson 2003) has also shown that starting music lessons at an early age, with strong parental support in the initial stages, is a factor that is "critical in determining whether children continue to be musicians or give up" (537). A study by Jorgensen (2001) with 106 conservatory students showed that the most accomplished performers had started music lessons earlier. Little is known, however, about the possible relationship between an early start and a student's motivation, interest in performance and creativity, interest in effortful practice, time spent practising, or feeling of competence. Our study examined these relationships. On the basis of past literature, we expected a younger age of starting lessons to be linked with positive outcomes on all of the variables studied.

\section{Method of Instruction}

Parents who are registering their children for piano lessons are sometimes faced with decisions regarding the choice of teaching method. Many pedagogues hold opinions on which method is best, but these opinions have rarely been 
underpinned by research. Only a handful of studies have compared methods of study, and these have focused on musical aptitude, musical achievement, and musical performance (Kitts 1993; Moorhead 2005). There are no comparative studies investigating the effect of different methods on outcomes other than those in the performance domain. We therefore aimed to perform exploratory analyses to examine links between the method of instruction and all the outcomes in our study. We compared four teaching methods: the conventional series of piano books used in North America, generally referred to as the traditional approach, as well as the Suzuki method, the Yamaha method, and the unique methods of a specific private school.

\section{Taking Group Lessons}

Parents might also face a decision about whether to register their child for group lessons. Group lessons are widely available to beginner students through programs such as Yamaha, Music for Young Children, and the Suzuki method. A number of benefits are often cited to promote group instruction. In terms of musical content, group instruction is believed to provide time to incorporate more musicianship activities (Beres 2001) such as ensemble playing, sightreading, harmonization, transposition, and creative activities (Burkett 1982). In terms of personal benefits, group lessons are expected to be an enjoyable interaction with peers, to motivate through positive feedback from both the teacher and peers, and to instil a sense of personal value (ibid.; Jackson 1980; Kim 2004). One study by Diehl (1980) has shown that participants in group lessons did just as well as participants in individual lessons on various indices of performance, including aural discrimination, knowledge of musical symbols, public performance, and transposition, and they did better in sight-reading. Little is known, however, about the effects of group lessons on most of the outcomes we studied. On the basis of the prevailing opinion that group lessons are beneficial, we expected group lessons to relate positively to our outcomes.

\section{Taking Piano Exams}

As the child pursues music lessons, the parents may have a say in whether or not their child participates in piano exams. Institutions that provide accreditations through an exam system advocate in favour of regular exams (Royal Conservatory of Music 2011). However, parents and music teachers often wonder if exams have negative consequences (Cutietta 2003; Grant 1980; Parker 2006). Salaman (1994) has considered how exams increase motivation and time spent practising, but has questioned whether this motivation is "primarily connected with music-making or exam-taking" (210). While graded examinations are often presented as non-competitive, and students are encouraged to only "compete against themselves," Salaman doubts that this is really the case, particularly because many parents believe that a teacher's reputation rests on their students' achievements in examinations. For Sloboda (1994), it is only when internal motivation is stimulated that an examination can be an incentive to continue music learning. Many studies in self-determination theory have shown 
that sources of external pressure like exams, deadlines, and tangible rewards sometimes increase the quantity of work a person produces, but often undermine the quality of the work and the individual's autonomous motivation (Deci, Koestner, and Ryan 1999; Ryan and Deci 20oob; Ryan and Weinstein 2009). The effect of exams has not been studied in the music domain, however. In our study, we predicted that taking exams would be linked with more time spent practising, but with poorer motivation (i.e., lower autonomous motivation, higher controlled motivation, and higher amotivation) and lower interest (in performance and creativity, and in effortful practice).

\section{Parents Sit In on Lessons and Help with Home Practice}

In this article, we focused on two aspects of parental involvement: sitting in on the child's music lessons, and assisting the child with home piano practice. Studies in the academic domain have shown that parental involvementoften in the form of helping with homework-is beneficial for improvements in reading achievement (Mize 1977), mathematics achievement (Gutman 1981; Wheeler 1984), and general academic achievement (Baker 1997; Epstein 1992; Grolnick et al. 2002; Hoover-Dempsey et al. 2001; Hoover-Dempsey and Sandler 1995; Keith et al. 1992; Spera 2005; Wilson 1976). Warton (1997) has established that although children understand the importance of doing homework to improve their competence, it will take many years before they take personal responsibility for completing their homework by themselves. Alderman (1999) has shown that a child will often need assistance to learn how to manage, plan, and prioritize use of time.

A number of studies have focused on the impact that parental involvement could have on musical achievement. Creech $(2001,2006)$ has shown that parental support is a better predictor of a music student's achievement than some other factors, including musical aptitude test results. Brokaw (1983) found a positive relationship between performance achievement and parental supervision of home practice. In fact, according to his study, in the initial stages of music learning, the amount of time that parents spend supervising home practice seem to be a predictor of successful achievement better than the amount of time a student will spend practising. Davidson et al. (1995) and Sloboda and Howe (1991) have also found that the most successful children often have parents who sat in on the lesson and took notes or spoke to the teacher at the end of the lesson, and supervised practice. McPherson and Zimmerman (2011) discuss how parental support is important in moving the child towards self-regulated learning in music, and McPherson and Renwick (2011) report that when children are beginners, their parents are especially likely to participate closely in their child's music practice. McPherson and Davidson (2002) state that music students have a better chance to experience success when their practice sessions are supported by the parent. The importance of parental influences on musical achievement is well recognized (Moore, Burland, and Davidson 2003; Sloboda and Davidson 1996), but their impact on piano students' motivation, interest in performance and creativity, time spent practising, or feeling of competence is not well documented. Only a few studies (Comeau, Huta, Liu 2015; 
Hallam 1998; Davidson et al. 1996) have shown that parents could be an important motivating factor for supporting practice. In our study, on the basis of previous findings regarding achievement, we expect parental involvement-in the form of helping with home practice and sitting in on lessons-to be linked with positive outcomes on the child variables we studied.

\section{Parents Give Rewards for Home Practice}

The third parental behaviour we wished to study was the practice of giving children rewards for doing piano practising. Bigler and Lloyd-Watts (1998) claim that "reward is one of the simplest and best motivational tools available," and while praise is highly valued, stickers and stars, and on "special occasions ... a lollipop" can help when a "little extra boost is needed" (37). Unfortunately, empirical findings in self-determination theory show that rewards and incentives sometimes encourage a person to increase the quantity of work, but tangible rewards in particular have a detrimental effect on the quality of motivation, whereas praise does not on average have a detrimental effect (Deci, Koestner, and Ryan 1999). Thus, we expected that giving tangible rewards may increase children's time spent practising, but would undermine their autonomous motivation for learning the piano.

\section{SUMMARY OF HYPOTHESES}

Hypothesis 1: The younger the age of starting lessons, the better the child outcomes

Exploratory Question 2: We did not have specific predictions regarding the effects of method of instruction, and thus our approach to this question was exploratory

Hypothesis 3: Children who had taken group lessons would have better outcomes

Hypothesis 4: Children who had taken exams would have better objective outcomes, such as exam performance scores and time spent practising, but poorer subjective outcomes, such as a feeling of competence, motives for playing the piano, interest in performance and creativity or effortful practice

Hypothesis 5: The more often the parent sat in on lessons, the better the child outcomes

Hypothesis 6: The more a parent helped with home practice, the better the child outcomes

Hypothesis 7: Compared to children receiving no rewards for good home practices, children receiving tangible rewards would have better objective outcomes, such as exam performance scores and time spent practising, but poorer subjective outcomes, such as a feeling of competence, motives for playing the piano, and interest 
in performance and creativity or effortful practice; children receiving praise would not differ on objective outcomes and would have equal or better subjective outcomes. Our approach to any other rewards the parents might give was exploratory.

Hypothesis 8: All of the effects predicted above would be weaker in the older children

\section{METHOD}

\section{Participants}

Participants were 173 children who had been taking piano lessons for at least one year, along with one of their parents. The participants were recruited in several cities in the province of Ontario, the province of Quebec, and the northeast United States (with approximately one-third of participants from each of these regions). We sampled students from seventy-four different piano teachers to obtain as diverse a sample as possible. The children were aged 6 to 16 , with mean age 10.89 (standard deviation 2.42), and 57 per ccent were female. Of the children, 59 per cent had two Caucasian parents, 16 per cent had one Caucasian and one Asian parent, 18 per cent had two Asian parents, 4 per cent had two African-American parents, and 3 per cent were of other mixed ethnic backgrounds. To ensure adequate group sizes, and because we used only ethnicity as a control variable, we dichotomized ethnicity into two groups in our analyses: Caucasian (children with two Caucasian parents), and Other (all other ethnic backgrounds combined).

\section{Procedure}

We used the Survey of Musical Interests (SMI) developed by the Piano Pedagogy Research Laboratory at the University of Ottawa (Desrochers et al. 2006). This self-report questionnaire has two components-one completed by the child and the other completed by one of the child's parents. The predictors (age of starting lessons, method of instruction, group lessons, parents sitting in on lessons, parents helping with home practice) and objective outcomes (exam performance scores and time spent practising) were reported by the child's parent, and the subjective outcomes (feeling of competence at the piano, motives for playing the piano, interest in performance and creativity, and interest in effortful practice) were reported by the child. The children and parents were assessed before or after a regular piano lesson or at a scheduled research session.

Participants were assessed by a trained assistant, either individually (the younger ones) or in a group setting (the older ones). In order to obtain the most authentic responses from children, their parents were not present while children were completing the questionnaire; instead, the parents filled out the parent portion of the questionnaire in another room. The children were assured that neither their parents nor their piano teachers would have access to their completed questionnaires. At the beginning of each child's assessment, 
the trained assistant provided both written and verbal instructions about the items on the questionnaire. The children were encouraged to raise any questions, concerns, or difficulties they had at any time during the interview. With the younger children, the assistants explained items one by one and let the participants answer before moving on to the next item. To aid the children with understanding items rated on Likert-type scales, the rating scales were presented visually, as shown in figure 1.

Not interesting at all $\leftrightarrow$ Very interesting

Working hard on a piece of music

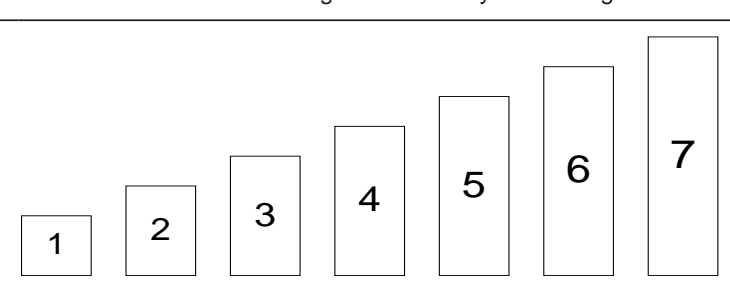

Figure 1. Sample item from the children's questionnaire

\section{Predictors}

Questions were presented in an open-ended format and completed by the parent. Age started was assessed with "How old was your child when he/she started taking piano lessons?" Years of lessons, which served as a control variable when analyzing age started, was assessed with "How long has your child been taking piano lessons?" The method of instruction for each child was recorded by the experimenter, based on the report of the piano instructor. Methods of instruction fell into four categories: traditional (conventional North American piano book series), Suzuki, Yamaha, and the unique curriculum of a specific private school. The following questions were presented in a yes/no format and completed by the parent. Whether the child has taken group lessons was assessed with "Has your child ever participated in group piano lessons?" Whether the child has taken exams was assessed with "Has your child taken any piano exam so far?" The following questions were rated on a Likert-type scale with response options $1=$ never, $2=$ seldom, $3=$ sometimes, $4=$ often, and $5=$ always, and completed by the parent. The frequency with which the parent sits in on lessons was assessed with "Do you sit in at your child's piano lesson?" The frequency with which the parent helps with home practice was assessed with "Do you ever help your child with his/her piano practice?"

The parent also completed the following question (rated $1=$ never, $2=$ seldom, 3 = sometimes, 4 = often, and $5=$ always): "Do you ever offer your child rewards for doing good practices?" This question was not used in analyses, but allowed us to gauge the degree of missing data for the following open-ended question, which we did use in analyses to assess the type of reward the parent gave most often: "If you reward your child for practising, what sort of rewards do you provide?" One of the authors read through the reward descriptions, identified four main categories of rewards, and coded each parental description 
as falling primarily into one of these four categories, or into a group of descriptions called "other" that either represented some other kind of reward or a description that was difficult to code. The four main categories of reward were: tangible (money, gift, or treat), praise, media/time (TV, videogame, computer time, free time), or social (outing, attention, time with friends). A second independent rater was then given the above description of the four main categories and the "other" category, and asked to categorize each reward description into one of them. The raters agreed 89 per cent of the time; where there was disagreement, the raters discussed the parent's description until they agreed on a category (settling on the second rater's categorization 67 per cent of the time). Of the 125 parents who reported giving rewards at least seldom on the item rated from 1 to 5, 11 did not report what type of reward they gave. Furthermore, 13 of the reward descriptions were placed in the "other" category. Thus, analyses with reward category were based on only 149 of the 173 participants.

\section{Child Outcomes}

\section{Piano Autonomous Motivation Scale (PAMS)}

We created sets of items to assess the different types of motivation addressed in self-determination theory (though we did not differentiate between identification and integration, a subtle distinction that has been difficult to make in other scales based on the theory as well). The root question of the PAMS read, "I learn to play the piano ______," and the items were rated by the child from 1 (not at all like me) to 7 (perfectly like me) (see the final list of items below). From a pool of thirty-one face valid items, we dropped thirteen items that clearly failed to load on the concept they were intended to represent in principal components analysis. This produced a set of eighteen items that, after closer examination, ${ }^{1}$ were grouped under three motivation variables for our

1 A principal components analysis was performed on the eighteen items. There were four eigenvalues above 1, but the scree plot suggested that a two-factor, three-factor, or four-factor solution was reasonable. Given that we theoretically expected either a five-factor solution (where all five types of motivation would separate) or a three-factor solution (consisting of amotivation, autonomous motivation-combining identification and intrinsic motivation-and controlled motivation-combining external regulation and introjection), we extracted a three-factor solution. The three-factor solution accounted for 58 per cent of the total variance (the two-factor solution captured less than 50 per cent of the total variance). We used an oblique rotation (Direct Oblimin, with Delta set at o) because the different types of motivation are known to be correlated. In the rotated solution, every item loaded primarily on the factor it was intended to represent, and only two items had cross-loadings exceeding .40 on a secondary factor. Note that Varimax rotation produced the same groupings of the items. When the five motivation scales were used separately, the Cronbach alphas were .86 for intrinsic motivation, .83 for identification, .64 for introjection, .68 for external regulation, and .82 for amotivation. The inter-correlations of the five scales showed a clear simplex pattern.

To develop a sense of how the PAMS would perform in a new sample, we randomly selected ten subsamples, each containing 75 per cent of the participants (this percentage ensured that each subsample would include enough participants for principal components analysis, but would exclude enough participants to develop a sense of what differing samples would produce). In all subsamples, four eigenvalues were above 1 , the scree indicated two to four factors, and a three-factor solution accounted for at least 55 per cent of the total variance. When extracting a three-factor solution, the items loaded largely as expected, with some exceptions (in five subsamples, the introjection items either loaded equally on the controlled motivation and autonomous motivation factors or somewhat more 
analyses: amotivation, autonomous motivation (the mean of identification and intrinsic motivation), and controlled motivation (the mean of external regulation and introjection).

The PAMS measures used in analyses were based on the following scales. There were five items representing intrinsic motivation ("because playing the piano is a lot of fun," "because it makes me feel good," "because I enjoy learning new things about music," "because I like the sound the piano makes," "because I enjoy learning new pieces"); two items representing identification and integration, which we will simply refer to as identification ("because I see myself as a musician," "because I want to be a musician when I grow up"); two items representing introjection ("because I would be ashamed if I stopped playing," "because I would feel bad if I didn't learn to play the piano"); three items representing external regulation ("because my parents would be disappointed if I stopped playing," "because my teacher would be disappointed if I stopped playing," "because my parents would be upset if I quit playing the piano"); and six items representing amotivation ("but it is a waste of my time," "but I don't see the point in learning to play the piano," "but I don't care if I play piano or not," "but learning to play the piano is not worth all the trouble," "but I don't feel excited about it," "but I don't know why I am doing it").

\section{Interest Scales}

We also created a set of interest items specifically for this study. They were completed by the child, being rated from 1 (not interesting at all) to 7 (very interesting). Interest in effortful practice was assessed with six items: "repeating a certain bar that needs practising," "practising a piece slowly," "practising scales," "playing with a metronome," "sight reading," and "working on a hard piece of music." Interest in performance and creativity was assessed with six items: "performing at a recital," "playing for my family or friends," "playing for my piano teacher," "taking a piano exam," "improvising," and "composing music."

on the autonomous motivation factor). Alphas across the subsamples were quite consistent, ranging .84 to .87 for intrinsic motivation, .80 to .85 for identification, .60 to .69 for introjection, .64 to .70 for external regulation, and .81 to .83 for amotivation. When using the five motivation scales separately, we obtained adequate simplex patterns (with the majority of correlations progressively declining away from the diagonal, except that in four subsamples, external regulation correlated similarly with identification and intrinsic motivation, and in five subsamples, introjection correlated similarly with identification and intrinsic motivation). Given that the principal components analysis did not lend support to a five-factor solution, and given that the alphas for external regulation and introjection were mostly below .80 and thus would likely be more reliable in combination (a revised version of the PAMS, where the external regulation and introjection scales have higher reliabilities, is forthcoming), we proceeded with three motivation variables in our analyses: amotivation, autonomous motivation (the mean of identification and intrinsic motivation), and controlled motivation (the mean of external regulation and introjection).

2 A principal components analysis of these items was performed. There were two eigenvalues above 1 and the scree plot clearly indicated a two-factor solution. We therefore extracted two factors, which accounted for 55 per cent of the total variance. After Varimax rotation (which is preferable when there isn't strong reason to expect factors to correlate, as it tends to produce more reliable results), we found that the items reflecting interest in effortful practising loaded on one factor, while the items reflecting interest in performance and interest in creativity loaded on the other factor, with 


\section{Feeling of Competence}

Here the question read, "When I compare my piano abilities with those of other students, I consider myself to be ." The options the child could choose from were "worse than most students," "worse than average," "about average," "better than average," and "better than most students," coded as 1 to 5 , respectively.

\section{Time Spent Practising}

Parents completed two open-ended questions: "On average, how many days a week does your child practise the piano?" and "On average, how long are her/his practice sessions?" To obtain the minutes of practice per week, we multiplied the answers to these two questions. This variable turned out to be positively skewed. We therefore employed the square root of this variable in analyses (though the untransformed variable was used for the descriptive statistics in table 1a).

\section{Exam performance}

Parents completed an open-ended question asking, "Can you provide the result of her/his last piano exam?" Because exam results were reported in various ways, they were coded as follows. If a percentage out of 100 was given, the exact percentage was used in analyses. In conformity with the main conservatory grading systems, a percentage of 95 was assigned if the exam result was "gold" or "first class honours with distinction"; 85 was assigned for "silver" or "first class honours"; 75 for "bronze" or "honours"; 70 for "good"; 65 for "pass"; and to prevent excessive negative skew, 50 was assigned for "fail."

\section{Analyses}

There were no missing data on the qualitative variables. There were few missing data on most quantitative variables (well below 5 per cent), and what was missing was imputed using expectation maximization. Only exam performance and type of reward had substantial degrees of missing data. For exam performance, we had data on 74 participants. For type of reward, we were able to analyze data on 149 participants, as detailed earlier. Analyses with all other variables were based on a sample size of 173. As shown in table 1a, all group sizes for type of reward were adequate, except when the outcome was exam performance, in which case we compared only no reward, praise, and tangible rewards; all group sizes for method of instruction were adequate, except when the outcome was exam performance, in which case we compared

one item loading similarly on both factors ("working on a hard piece of music"). (Note that Direct Oblimin rotation, with Delta o, produced the same results.) We felt that the cross-loading item fit thematically more with the items representing effortful aspects of practice, and retained it on that scale. We therefore proceeded to use two interest scales in our analyses, one called interest in performance and creativity (alpha .85), and the other called interest in effortful practice (alpha .78). 
only traditional and private school. Analyses were performed using SPSS. ${ }^{3}$ We used a correlation $(r)$ when examining the relationship between a numerical predictor and a numerical outcome (the numerical variables were: age started, years played, time spent practising, exam performance, and variables with ratings scales such as 1-7) or standardized regression coefficients when examining the relationship between multiple numerical predictors and a numerical outcome. We used a chi-squared contingency test $\left(\chi^{2}\right)$ when examining the relationship between a categorical predictor and a categorical outcome (the categorical variables were: method of instruction, has taken group lessons, has taken exams, and type of reward). When examining the relationship between a categorical predictor and a numerical outcome, we used an independent-samples $t$-test $(t)$ when the categorical variable had two categories, and an $F$-test ( $F$ test) when the categorical variable had three or more categories. In reporting the results, we use " $p<.05$ " or ${ }^{*}$ when we can be confident that there was a relationship between variables, " $p<.01$ " or ${ }^{* *}$ when we can be highly confident, and " $p<.10$ " or $\dagger$ when we can be fairly confident but the finding warrants replication in future research.

\section{RESULTS}

\section{Descriptives}

Table 1a provides the descriptive statistics for demographic variables, predictors, and child outcomes in the study. For quantitative variables, the descriptive statistics are the range, mean, and standard deviation. For qualitative variables, the descriptive statistics are the labels, frequencies, and percentages (given as percentage of available data) represented by each category. Table $1 \mathrm{~b}$ shows the number of piano students in each of four categories: children who started early (before age seven) and had not played long (fewer than five years), children who started early and had played longer, children who started later and had not played long, and children who started later and had played longer. This information provides a background for the interactions we tested between ages started and years played (though these variables were treated as quantitative when testing the interactions).

3 Age of starting lessons was not analyzed in the same way as the other predictors because it was confounded with years of lessons. To tease apart the effects of these two variables, we performed multiple regressions where the predictors were age started, years played, and the interaction of age started and years played as the independent variables (after controlling for gender and ethnicity). For method of instruction, we obtained the omnibus F-test with univariate GLM (controlling for gender, ethnicity, and current age), potentially following up with pairwise comparisons (Bonferroni corrected to reduce the risk of obtaining spurious results) between the four methods of instruction. When comparing the no reward category with tangible rewards and with praise, we obtained planned contrasts with univariate GLM (controlling for gender, ethnicity, and current age), because we had specific hypotheses. When comparing the no reward category with media/time rewards and with social rewards, we obtained the omnibus F-test with univariate GLM (controlling for gender, ethnicity, and current age), following up with Sidak-corrected comparisons with the no reward category, because our approach to these comparisons was exploratory. When analyzing history of group lessons, history of exams, parent sitting in on lessons, or parent helping with home practice, we performed a multiple regression with the given predictor as the independent variable (controlling for gender, ethnicity, and current age), and each child outcome in turn as the dependent variable. 
Table 1a. Descriptive statistics

\begin{tabular}{|c|c|c|}
\hline & Range or group sizes & $\begin{array}{l}\text { Mean and standard } \\
\text { deviation or percentages }\end{array}$ \\
\hline \multicolumn{3}{|l|}{ Demographic variables } \\
\hline Current age & $6-16$ & $M=10.89, S D=2.42$ \\
\hline Gender & Female, male & $57 \%$ female \\
\hline Ethnicity & Caucasian, other & $59 \%$ Caucasian \\
\hline \multicolumn{3}{|l|}{ Predictors } \\
\hline Age started & $2-14$ & $M=5.87, S D=1.84$ \\
\hline $\begin{array}{l}\text { Years of lessons } \\
\text { Years of lessons when age started }<7 \\
\text { Years of lessons when age started } \geq 7\end{array}$ & $\begin{array}{l}1-12 \\
2-12 \\
1-8\end{array}$ & $\begin{array}{l}M=5.00, S D=2.09 \\
M=5.23, S D=1.96 \\
M=4.37, S D=2.28\end{array}$ \\
\hline Has taken group lessons & Yes, no & $37 \%$ Yes \\
\hline Has taken exams & Yes, no & $56 \%$ Yes \\
\hline Parent sits in on lessons (rated 1-5) & $1.00-5.00$ & $M=3.36, S D=1.55$ \\
\hline Parent helps with home practice (rated 1-5) & $1.00-5.00$ & $M=3.09, S D=1.34$ \\
\hline $\begin{array}{l}\text { Type of reward } \\
\text { (Values in parentheses are for exam scores, } \\
\text { since these were not available for all participants) }\end{array}$ & $\begin{array}{l}48(16) \text { None } \\
21(13) \text { Praise } \\
23(8) \text { Media/time } \\
16 \text { (5) Social } \\
42 \text { (22) Tangible }\end{array}$ & $\begin{array}{l}32 \%(25 \%) \text { None } \\
14 \%(20 \%) \text { Praise } \\
15 \%(13 \%) \text { Media/time } \\
11 \%(8 \%) \text { Social } \\
28 \%(34 \%) \text { Tangible }\end{array}$ \\
\hline $\begin{array}{l}\text { Method of instruction } \\
\text { (Values in parentheses are for exam scores, } \\
\text { since these were not available for all participants) }\end{array}$ & $\begin{array}{l}59 \text { (17) Traditional } \\
21 \text { (2) Suzuki } \\
21 \text { (7) Yamaha } \\
72 \text { (48) Private school }\end{array}$ & $\begin{array}{l}34 \%(23 \%) \text { Traditional } \\
12 \%(3 \%) \text { Suzuki } \\
12 \%(10 \%) \text { Yamaha } \\
42 \%(65 \%) \text { Private } \\
\text { school }\end{array}$ \\
\hline \multicolumn{3}{|l|}{ Child outcomes } \\
\hline Autonomous motivation (rated $1-7$ ) & $1.00-7.00$ & $M=4.65, S D=1.42$ \\
\hline Controlled motivation (rated 1-7) & $1.00-7.00$ & $M=3.88, S D=1.35$ \\
\hline Amotivation (rated 1-7) & $1.00-5.50$ & $M=2.29, S D=1.25$ \\
\hline Interest in performance and creativity (rated 1-7) & $1.75-7.00$ & $M=5.18, S D=1.35$ \\
\hline Interest in effortful practice (rated 1-7) & $1.00-7.00$ & $M=3.90, S D=1.35$ \\
\hline Feeling of competence (rated 1-5) & $1.00-5.00$ & $M=3.60, S D=0.91$ \\
\hline $\begin{array}{l}\text { Time spent practising (average minutes per } \\
\text { week) }\end{array}$ & $9-630$ & $M=164.94, S D=118.09$ \\
\hline Exam performance (\%) & $50-97$ & $M=81.66, S D=9.08$ \\
\hline
\end{tabular}

$M=$ Mean; $S D=$ Standard deviation

Table 1b. Number of piano students when crossing age started with years played

\begin{tabular}{lrr}
\hline & Years played: fewer than 5 & Years played: 5 or more \\
\hline Age started: before 7 & 52 & 70 \\
Age started: 7 or later & 25 & 26 \\
\hline
\end{tabular}




\section{Demographic Variables}

The demographic variables-current age, gender, and ethnicity-had significant relationships with some of the predictors and child outcomes in this study. Current age related positively to age of starting lessons $(r=.51, p<.01)$, and years of lessons to date $(r=.67, p<.01)$; it related negatively to having the parent sit in on lessons $(r=-.22, p<.01)$, help with home practice $(r=-.33, p<.01)$, and give rewards for practising $(r=-.25, p<.01)$; and related negatively to interest in performance and creativity $(r=-.21, p<.01)$. For gender, boys scored higher than girls on controlled motivation $(t=2.70, p<.01)$, but also higher on interest in performance and creativity $(t=2.12, p<.05)$. For ethnicity, compared to children with two Caucasian parents, children from other backgrounds scored lower on interest in performance and creativity $(t=2.09, p<.05)$, were more likely to have participated in group lessons $\left(\chi^{2}=4.65, p<.05\right)$, were more likely to have taken a piano exam $\left(\chi^{2}=8.19, p<.01\right)$, and also showed differences in the teaching methods they received $\left(\chi^{2}=16.80, p<.01\right)$, such that they were overrepresented in the Yamaha method and the private school but underrepresented among students in the traditional method and the Suzuki method. Because of these multiple links with the demographic variables, our remaining analyses controlled for gender and ethnicity and in most cases current age (except for the analyses with age started and years played, where current age would be redundant).

\section{Age Started}

As shown in table 2a, the earlier the child had started taking piano lessons, the higher the interest in performance and creativity, feeling of competence, and time spent practising, regardless of the number of years each had played (negative signs on the regression coefficients mean that children who started younger had the higher scores on outcomes). The longer the child had played, the more time spent practising, regardless of the age at which he or she started. Furthermore, age started and years played interacted significantly in the case of three child outcomes: autonomous motivation, amotivation, and exam performance. These interactions are examined in greater detail in table $2 b$ and are displayed graphically in figure 2 . In table $2 b$, we flag marginally significant effects to highlight a consistent pattern. In the first two columns of table $2 b$, we report the simple main effects of years played (treated as a quantitative variable); we found that children who started lessons at age seven or later showed a marginal rise in amotivation, and a marginal decline in exam performance, the longer they had played; in contrast, children who had started before the age of seven remained steady on all three child outcomes. In the last two columns of table $2 b$, we report the simple main effects of age started (treated as a quantitative variable); we found that starting age played little role among children who had played fewer than five years; but among those who had played for five years or more, children who had started lessons earlier had stronger autonomous motivation, and marginally higher exam performance. Note that the relationship of age started, years played, and current age with each outcome was 
linear, and thus the effects in figure 2 and table $2 \mathrm{~b}$ are not merely artifacts of non-linearity. In sum, our findings supported Hypothesis 1: starting piano lessons at an earlier age was linked with positive outcomes.

Table 2a. Relating each child outcome to age started, years played, and their interaction, as standardized regression coefficient

\begin{tabular}{lccr}
\hline \multicolumn{1}{c}{ Child outcomes } & Age started & Years played & $\begin{array}{r}\text { Age started* } \\
\text { years played }\end{array}$ \\
\hline Autonomous motivation & -.13 & .00 & $-.20^{*}$ \\
Controlled motivation & -.01 & .02 & .12 \\
Amotivation & .11 & .09 & $.20^{*}$ \\
Interest in performance and creativity & $-.23^{* *}$ & -.13 & -.15 \\
Interest in effortful practice & -.08 & -.07 & -.13 \\
Feeling of competence & $-.29^{* *}$ & .15 & -.01 \\
Time spent practising & $-.27^{* *}$ & $.20^{* *}$ & -.13 \\
Exam performance & -.08 & -.21 & $-.38^{* *}$ \\
\hline
\end{tabular}

Note. The analyses in this table control for gender and ethnicity. A negative effect for age started indicates that the younger a child started, the higher their score on the child outcome.

${ }^{*} p<.05 ;{ }^{* *} p<.01$

Table 2b. Examining the significant interactions in table 2a: Standardized regression coefficient for simple main effect of years played or age started

\begin{tabular}{lrrrr}
\hline & \multicolumn{2}{c}{ Simple main effect of years played } & Simple main effect of age started \\
\cline { 2 - 5 } \multicolumn{1}{c}{ Child outcomes } & $\begin{array}{l}\text { Started } \\
<\text { age } 7\end{array}$ & $\begin{array}{r}\text { Started } \\
\geq \text { age } 7\end{array}$ & $\begin{array}{r}\text { Has played } \\
<5 \text { years }\end{array}$ & $\begin{array}{r}\text { Has played } \\
\geq 5 \text { years }\end{array}$ \\
\hline Autonomous motivation & .14 & -.20 & .06 & $-.20^{*}$ \\
Amotivation & .01 & $.25^{\dagger}$ & -.04 & .11 \\
Exam performance & -.03 & $-.51^{\dagger}$ & .17 & $-.23^{\dagger}$ \\
\hline
\end{tabular}

Note. The analyses in this table control for gender and ethnicity. A negative effect for age started indicates that the younger a child started, the higher their score on the child outcome. ${ }^{\dagger} p<.10 ;{ }^{*} p<.05 ;{ }^{* *} p<.01$ 

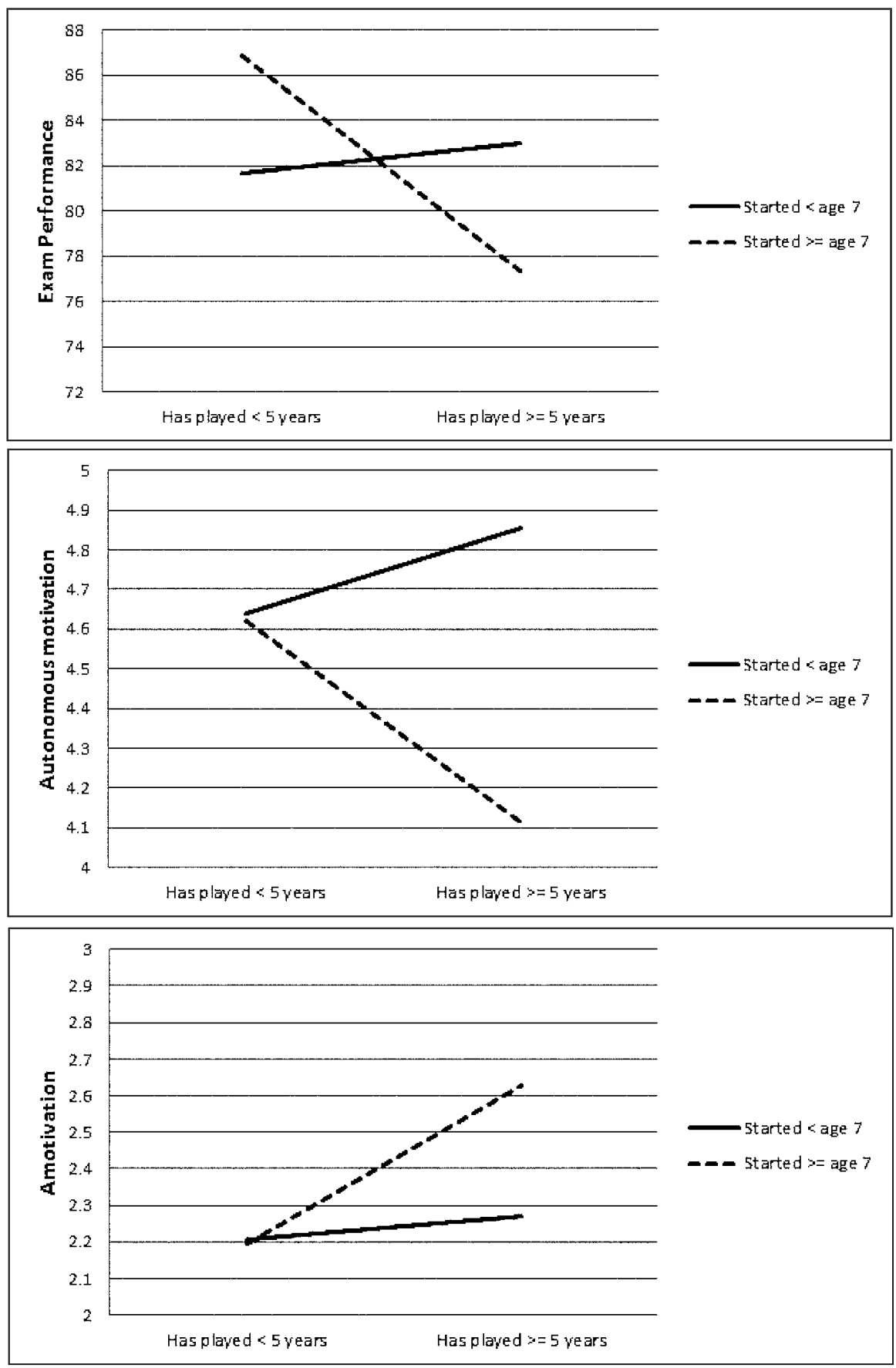

Figure 2. Interactions between age started and years of lessons when predicting autonomous motivation, amotivation, and exam performance. 


\section{Method of Instruction}

As shown in the first column of table 3 , the method of instruction played little role in the child outcomes, except in the case of controlled motivation. To further explore the significant finding for controlled motivation, we performed pairwise comparisons of the marginal means (Bonferroni corrected to reduce the risk of obtaining spurious results) between the four methods of instruction. The results show that students taking lessons at the private piano school scored significantly higher on controlled motivation than did students following the traditional method (the estimated marginal means were as follows: 3.43 for traditional, 4.12 for private school, 3.99 for Suzuki, and 4.23 for Yamaha). Overall, our findings regarding Exploratory Question 2 show that method of piano instruction had relatively little relationship with the child's objective or subjective outcomes.

Table 3. Relating a given predictor to each child outcome, as an F-test or standardized regression coefficient

\begin{tabular}{|c|c|c|c|c|c|}
\hline & $F$-test & \multicolumn{4}{|c|}{ Standardized regression coefficient } \\
\hline & $\begin{array}{l}\text { Method of } \\
\text { instruction }\end{array}$ & $\begin{array}{r}\text { Has taken } \\
\text { group } \\
\text { lessons }\end{array}$ & $\begin{array}{r}\text { Has taken } \\
\text { exams }\end{array}$ & $\begin{array}{r}\text { Parent } \\
\text { sits in on } \\
\text { lessons }\end{array}$ & $\begin{array}{l}\text { Parent helps } \\
\text { with practice }\end{array}$ \\
\hline Autonomous motivation & .87 & -.02 & -.15 & $.18^{*}$ & .08 \\
\hline Controlled motivation & $3.64^{*}$ & $.20^{* *}$ & .08 & .09 & .13 \\
\hline Amotivation & 1.82 & .06 & .06 & .12 & .15 \\
\hline $\begin{array}{l}\text { Interest in performance and } \\
\text { creativity }\end{array}$ & 1.23 & -.05 & $-.16^{*}$ & $.20^{* *}$ & $.17^{*}$ \\
\hline Interest in effortful practice & .01 & -.13 & -.10 & .12 & .02 \\
\hline Feeling of competence & 2.22 & -.04 & .06 & $.27^{* *}$ & .12 \\
\hline Time spent practicing & .30 & .11 & $.27^{* *}$ & $.18^{*}$ & $.37^{* *}$ \\
\hline Exam performance & .18 & $.25^{* *}$ & NA & .19 & $.28^{*}$ \\
\hline
\end{tabular}

Note. The analyses in this table control for gender, ethnicity, and current age.

When examining the link between method of instruction and exam performance, we only compared traditional and private school, as the sample sizes for the other two methods were too small for generalization.

NA: Exam grades could not be obtained for students who did not take exams.

${ }^{\star} p<.05 ;{ }^{* *} p<.01$.

\section{Has Taken Group Lessons}

As shown in the second column of table 3 , children who had taken group lessons in the past scored higher on exam performance, but had higher controlled motivation. This pattern was somewhat at odds with Hypothesis 3, where we had predicted that group lessons would be beneficial, i.e., would not have drawbacks. Instead, the results suggested a double-edged effect, with a positive outcome (higher exam performance) as well as a negative outcome (higher controlled motivation). 


\section{Has Taken Exams}

As shown in the third column of Table 3 , children who had taken exams in the past spent more time practising, but had lower interest in performance and creativity. This supported Hypothesis 4, showing a double-edged effect such that exams related to higher scores on an objective outcome, but lower scores on a subjective outcome.

\section{Parent Sits in on Lessons}

As shown in the fourth column of Table 3, the more often a parent sat in on the child's lessons, the higher the child's autonomous motivation, interest in performance and creativity, feeling of competence, and time spent practising. This supported Hypothesis 5: when the parent sat in on lessons, the child had positive outcomes.

\section{Parent Helps with Home Practice}

As shown in the fifth column of table 3, the more often a parent helped the child with home piano practice, the higher the child's interest in performance and creativity, time spent practising, and exam performance. This supported Hypothesis 6: when the parent helped with practice, the child showed positive outcomes.

\section{Parent Gives Rewards for Practising}

Each of the first four columns of table 4 gives the difference between a given type of reward and no reward, as a standardized mean difference. ${ }^{4}$ We found that tangible rewards were associated with more practice and with a higher feeling of competence, but also with a higher level of controlled motivation, when compared with no reward. Neither praise nor social rewards differed from no reward on the outcomes studied. Media/time rewards were associated with more time spent practising. This partially supported Hypothesis 7 , showing a double-edged effect such that tangible rewards related to higher scores on an objective outcome, but poorer scores on a subjective outcome-motivation; however, tangible rewards were also associated with a positive subjective outcome-a higher feeling of competence. As predicted, praise did not differ from no rewards in either objective or subjective outcomes. Regarding the remaining types of rewards, we found that media/time rewards related to a positive objective outcome but not to any of the subjective outcomes studied.

4 The last column gives the omnibus F-test of a univariate GLM comparing the five reward categories (i.e., no reward and four types of reward). As noted earlier, our hypothesis tests regarding tangible rewards and praise are planned contrasts (and thus the corresponding $F$-tests need not be significant), while our exploratory analyses of media/time rewards and social rewards are Sidak-corrected post hoc tests (to be interpreted only if the omnibus F-test is significant, though we present all of them for the sake of completeness). 
Table 4. Comparing each reward category with no reward, as a standardized mean difference

\begin{tabular}{|c|c|c|c|c|c|}
\hline \multirow[b]{2}{*}{ Child outcomes } & \multicolumn{4}{|c|}{ Standardized mean difference } & \multirow[b]{2}{*}{$F$-test } \\
\hline & $\begin{array}{l}\text { Tangible } \\
\text { reward }^{\mathrm{a}}\end{array}$ & Praise $^{a}$ & $\begin{array}{l}\text { Media/time } \\
\text { reward }^{\mathrm{b}}\end{array}$ & $\begin{array}{r}\text { Social } \\
\text { reward }^{\mathrm{b}}\end{array}$ & \\
\hline Autonomous motivation & -.19 & -.17 & -.09 & -.66 & 1.48 \\
\hline Controlled motivation & $.42^{*}$ & .04 & .20 & .38 & 1.33 \\
\hline Amotivation & .38 & -.14 & .08 & .55 & 2.00 \\
\hline $\begin{array}{l}\text { Interest in performance and } \\
\text { creativity }\end{array}$ & -.13 & -.16 & .15 & -.63 & 1.99 \\
\hline Interest in effortful practice & -.23 & -.22 & -.27 & -.46 & .79 \\
\hline Feeling of competence & $.44^{*}$ & -.14 & .14 & .14 & 1.56 \\
\hline Time spent practising ${ }^{\mathrm{C}}$ & $.48^{* *}$ & .29 & $.64^{*}$ & .45 & $3.24^{*}$ \\
\hline Exam performance & -.40 & -.28 & NA & NA & 1.45 \\
\hline \multicolumn{6}{|c|}{$\begin{array}{l}\text { Note. The analyses in this table control for gender, ethnicity, and current age. } \\
\text { a Analyses for tangible reward and praise tested a priori hypotheses and thus used planned contrasts. } \\
\text { b Analyses for media/time reward and social reward were exploratory and thus used Sidak corrected post hoc } \\
\text { comparisons. } \\
\text { c The inferential statistics for time spent practicing were performed with the transformed variable, but the standardized } \\
\text { mean difference reported in this table is based on the untransformed variable for ease of interpretation. } \\
\text { NA: Category sample sizes were not large enough for purposes of generalization. } \\
{ }^{*} p<.05 ;{ }^{* \star} p<.01\end{array}$} \\
\hline
\end{tabular}

\section{Moderations by Age}

We then examined whether any of the relationships between predictors and outcomes were moderated by the child's current age. To test these moderations, we repeated all of the above analyses, this time adding an interaction between current age and the predictor being studied (except when the predictor was age started or years played, where current age would be a redundant predictor). For method of instruction, because Yamaha and Suzuki are geared towards younger children, we used a dichotomous variable coded as $1=$ Yamaha/Suzuki, o $=$ traditional/private school. We found very few moderations: one interaction was statistically significant (the first one listed below) and six were marginally significant. We therefore describe the moderations verbally rather than detailing the numeric results, and we describe both the significant result and the marginal results, to see if the trends were in the direction predicted. Five of the seven moderations indicated that the parental decisions we studied had less impact as children got older; in the older children: there was a less negative link between reward-giving and interest in performance and creativity; there was a less positive link between parents sitting in on lessons and controlled motivation; there was a less positive link between taking exams and amotivation; there was a less positive link between Yamaha/Suzuki (as opposed to traditional/private school) and autonomous motivation; and there was a less positive link between Yamaha/Suzuki (as opposed to traditional/private school) and feeling of competence. One of the seven moderations indicated greater impact: as children got older, there was a stronger negative link between taking exams and interest in performance and creativity. And one of the seven moderations indicated a shift from benefits to drawbacks: in younger children, the link 
between taking group lessons and autonomous motivation was slightly positive, while in older children, it was slightly negative.

Overall, though, there was a smaller number of moderations than might be expected, so that support for Hypothesis 8 was partial. ${ }^{5}$

\section{Discussion}

Our results indicated that our variables can be organized roughly into three groups: (1) those that had relatively little relationship with the outcomes studied, like the methods of instruction; (2) those that had some problematic negative correlates, including giving the child rewards for practising, taking piano exams, and taking group lessons; and (3) those that had various positive correlates, including helping the child with home practice, sitting in on the child's lessons, and starting at a younger age.

The interactions between age started and years played were significant. We found that the earlier a child had started lessons, the higher the child's interest in performance and creativity, feeling of competence, and time spent practising, even after controlling for the number of years the child had played. On the other hand, the later a child had started, the more he or she showed declines over years played in autonomous motivation and exam performance, and the more each showed a rise in amotivation. Children who had started before the age of seven, however, remained steady on these variables.

We found that children who started lessons earlier tended to feel more competent at playing, which likely reflects the growth of competence over time. The age of starting piano lessons and the number of years the child had taken piano lessons showed a positive impact on the amount of practice. Perhaps children who started early tended to practise more because piano became an integral part of their lives, i.e., they saw piano practice more as a matter of course than as a chore. Children who had started later showed steady declines over years played in autonomous motivation and exam performance, and they showed a rise in amotivation. That could be partly explained by the fact that as children get older, they become more aware of where they stand in the difficulty and complexity of the repertoire they are playing. If they started piano at age five, by the time they are ten years old, they have reached an intermediate level of performance (repertoire is more advanced and technique is more impressive); but if they started after age seven, by the time they get to age ten, they are often still playing at a beginner's level (repertoire is much simpler and less demanding technically). At ten or twelve years old, it feels more exciting to play a Beethoven sonata than to play an easy Bach minuet or one of the simple Clementi sonatinas. That in itself can be discouraging for children who started late, especially when they compared themselves to other students.

5 The number of moderations was small, even with only 50 per cent power to detect marginal results, if we assume a partial $R$-squared as small as 1.5 per cent for an interaction (using $G^{\star}$ Power 3.1.2). If we include the marginal findings, five of the seven moderations were in the expected direction, though, such that effects became weaker as children became older. 
The methods of instruction that we had selected (Yamaha, Suzuki, traditional, and a curriculum developed by a private piano school) were unrelated to the child outcomes (except that private school children had higher controlled motivation than children in the traditional method). We have chosen to report results for this variable, although it shows no significant effects, because we believe that the absence of effects is very revealing. Considering that teachers tend to hold very strong views about which music method is the best, and that they diligently promote the philosophy of the method they have chosen and often hold negative views about other teaching approaches, it was enlightening to see that methods of instruction had so little impact on the child outcomes we studied.

Taking group lessons showed double-edged patterns, relating positively to the objective measures (time spent practising or exam performance), but also relating to poorer subjective experiences (higher controlled motivation, higher amotivation, and/or lower interest in performance and creativity). These findings were at odds with our expectations and with how group lessons are typically perceived, as group lessons are generally seen positively by music specialists, especially in stimulating motivation and contributing to a child's enjoyment of music learning. Perhaps being in a group creates constant pressure, as a student is always performing in front of others and may feel that peers are always evaluating how well one is doing, and may develop introjected motivation by comparing oneself with others. Group lessons may also be reminiscent of the classroom where children have to wait their turn and have to deal with the frustrations of witnessing others progress faster or slower than themselves.

On balance, taking exams did not seem particularly beneficial, showing an objective benefit at a subjective cost. This lends empirical support to the uneasiness that many parents and teachers feel toward this practice. The finding is also very much in line with many studies in self-determination theory, showing that external pressures like exams often undermine autonomous motivation. Nevertheless, studies on self-determination theory also show that the kind of feedback provided by exams can be beneficial if the student is able to perceive the exam as merely a source of information to help hone one's skill rather than a reflection of personal worth (called an informational approach rather than ego-involvement), and if the student sees the exam as a way of comparing current performance with past performance rather than a way of comparing oneself against other people (called a mastery orientation rather than a performance/ego orientation) (Deci, Koestner, and Ryan 1999; Ryan 1982; Ryan and Deci 2000a, 2000b). Thus, there may be a subset of piano students for whom taking exams has no negative effect or even has a positive effect-this would be worth examining in future research.

Giving the child tangible rewards for playing the piano was associated with more time spent practising, but also with higher controlled motivation and lower interest in performance and creativity. Children receiving rewards in the form of praise, computer/television time, or social activities did not differ from children receiving no rewards. This is consistent with studies in the self-determination theory literature showing that rewards can increase the quantity 
of work but simultaneously undermine motivation. Praise did not show the detrimental effects typically associated with tangible rewards, as shown in previous research. Media/time rewards may be experienced as fairly autonomous, because the child decides how to use his or her time, and we did not find any apparent costs, so this may be a way to go.

Having parents sit in on lessons or having parents help with home practice was positively related to the child outcomes, relating to autonomous motivation, interest in performance and creativity, feeling of competence, time spent practising, and/or exam performance. It is likely that these benefits arise at least in part because sitting in on lessons gives the child the message that the parent genuinely cares about piano playing and is engaged in the process with the child, which may lead the child to embrace and internalize piano playing more deeply. Like sitting in on lessons, helping with home practice may give the child a sense of being genuinely supported and further provides concrete assistance with progress.

This article has demonstrated the importance of ongoing parental involvement; this is particularly interesting, considering that, traditionally, parents are not invited to take part in their child's piano education. Many teachers are reluctant to allow parents to attend lessons, believing that their presence will disturb the child. It is not uncommon for a parent to sit in the hallway or in the car waiting for the lesson to end, while the parent's presence in the studio could be beneficial. From the parents' standpoint, it is interesting to note that they often help their children with school homework, but they may not think of helping in a similar way with piano practice.

The lesson learned from this study is that parents indeed can play a significant role in a child's piano education, but not always in the ways that were assumed. Though it may be worthwhile for parents to debate whether their child is among those who can benefit from a certain teaching method, group lessons, exams, or rewards, our findings indicate that it is worth investing more energy into actively participating in the child's piano education. This take-home message is equally important for music educators and is a call to more actively include parents as part of the child's music education team.

More attention should be given in future research to the effects for age started, as it addresses the important question of a critical period for music learning, while controlling for the potential confounding role of years played. The quality of parental involvement would also be a good avenue for follow-up research. It would be important to identify, in the context of self-determination theory, which parental style intervention most constructively supports a child's musical development.

This article sheds new light on some long-held assumptions about piano pedagogy and student engagement. Contrary to popular opinion, we found that the method of piano instruction had little effect on the child, piano exams and group lessons were decidedly a mixed blessing, and allowing parents to sit in on lessons was related to multiple benefits. We would like to see more research on these points, as they suggest that the music community may need to shift attention toward greater parental engagement. 


\section{REFERENCES}

Alderman, M. K. 1999. Motivation to learn. Mahwah, NJ: Lawrence Erlbaum Associates.

Baker, A. 1997. Parent involvement in children's education: A critical assessment of the knowledge base. New York: American Education Research Association.

Bastien, J. W. 1976. A parent's guide to piano lessons. San Diego, CA: Kjos West. —_ 1993. How to teach piano successfully, 3rd ed. San Diego, CA: Kjos.

Bellavia, C. 2006. When to start music lessons: My child loves music-so what should I do? An age-by-age guide to the best start in music education. http://www.childrensmusicworkshop.com/resources/articles/whentostart. html.

Beres, K. 2001. Group teaching in the independent piano studio: An annotated bibliography. Roland Keyboard Educator 5 (2): 12-21.

Bigler, C. L., and V. Lloyd-Watts. 1998. Studying Suzuki piano: More than music: A handbook for teachers, parents, and students, 2nd ed. Miami: Summy-Birchard.

Brokaw, J. P. 1983. The extent to which parental supervision and other selected factors are related to the achievement of musical and technical-physical characteristics of beginning instrumental music students. PhD diss., University of Michigan.

Burkett, T. A. 1982. The challenge of group piano teaching and the rewards. Music Educators Journal 69 (3): 31-3.

Comeau, G., V. Huta, and Y. Liu. 2015. Work ethic, motivation and parental influences in Chinese and North American children learning to play the piano. International Journal of Music Education 33 (2): 181-94.

Creech, A. 2001. Play for me: An exploration into motivations, issues and outcomes related to parental involvement in their children's violin study. MA thesis, University of Sheffield, UK.

—_. 2006. Dynamics, harmony and discord: A systems analysis of teacherpupil-parent interaction in instrumental learning. PhD diss. , Institute of Education, University of London, UK.

Cutietta, R. A. (2003). Raising musical kids: A guide for parents. Oxford: Oxford University Press.

Dai, D. Y., and R. Schader. 2001. Parents' reasons and motivations for supporting their child's music training. Roeper Review 24 (1): 23-26.

Davidson, J. W., M. J. A. Howe, D. G. Moore, and J. A. Sloboda. 1996. The role of parental influences in the development of musical performance. British Journal of Developmental Psychology 14:399-412.

Davidson, J. W., M. J. A. Howe, and J. A. Sloboda. 1995. The role of parents and teachers in the success and failure of instrumental learners. Bulletin of the Council for Research in Music Education 127:40-4, http://www.jstor.org/ stable/40318764.

Deci, E. L., R. Koestner, and R. M. Ryan. 1999. A meta-analytic review of experiments examining the effects of extrinsic rewards on intrinsic motivation. Psychological Bulletin 125:627-68. 
Desrochers, A., G. Comeau, N. Jardaneh, and I. Green-Demers. 2006. L'élaboration d'une échelle pour mesurer la motivation chez les jeunes élèves en piano. Revue de recherche en éducation musicale 24:13-33.

Diehl, L. P. 1980. An investigation of the relative effectiveness of group and individual piano instruction on young beginners in an independent music studio utilizing an electropiano laboratory. DMA diss., University of Southern California.

Epstein, J. L. 1992. School and family partnerships. In Encyclopedia of Educational Research, 6th ed., ed. M. Alkin, 1139-51. New York: MacMillan.

Grant, M. 1980. Your child and the piano: How to enrich and share in your child's musical experience. Don Mills, ON: General Publishing.

Grolnick, W., S. Gurland, W. DeCourcey, and K. Jacob. 2002. Antecedents and consequences of mother's autonomy support: An experimental investigation. Developmental Psychology 38 (1): 143-55.

Gutman, M. B. 1981. Parent involvement and children's mathematic achievement. Dissertation Abstracts International 42 (12): 5049A. University Microfilms no. DA8209306, 126.

Hallam, S. 1998. Instrumental teaching: A practical guide to better teaching and learning. Oxford: Oxford University Press.

Hodges, D. A. 2006. The musical brain. In The child as musician: A handbook of musical development, ed. G. E. McPherson, 51-68). Oxford: Oxford University Press.

Hoover-Dempsey, K. V., A. C. Battiato, J.M. T. Walker, R. P. Reed, J. M. DeJong, and K. P. Jones. 2001. Parental involvement in homework. Educational Psychologist 36 (3): 195-209.

Hoover-Dempsey, K. V., and H. M. Sandler. 1995. Parental involvement in children's education: Why does it make a difference? Teachers College Record 97 (2): 310-31.

Jackson, A. 1980. The effect of the group size on individual achievement in beginning piano classes. Journal of Research in Music Education 28 (3): 162-6.

Jonas, A. 1988. Children studying music: (Questions most asked by parents). Secaucus, NJ: Distributed by Warner Bros.

Jorgensen, H. 2001. Instrumental learning: Is an early start a key to success? British Journal of Music Education 18 (3): 227-39.

Kazdan, R. 2002. A parent's guide to successful piano lessons, 2nd ed. Toronto: Palmerston.

Keith, T. Z., P. B. Keith, P. G. Bickley, and K. Singh. 1992. Effects of parental involvement on eighth grade achievement: LISREL analysis of NELS-88 data. Paper presented at the Annual Meeting of the American Educational Research Association, San Francisco.

Kim, C. 2004. Nurturing students through group lessons. American Music Teacher 54 (1): 28-31.

Kitts, W. L. 1993. The effects of Edwin Gordon's rhythmic learning sequence on private traditional piano and Suzuki piano students. MMEd diss., University of Louisville. 
Lehmann, A. C. 1997. The acquisition of expertise in music: Efficiency of deliberate practice as a moderating variable in accounting for sub-expert performance. In Perception and cognition of music, ed. I. Deliège and J. A. Sloboda, 161-87. Hove, East Sussex: Psychology.

McPherson, G. E. 2009. The role of parents in children's musical development. Psychology of Music 37 (1): 91-110.

McPherson, G. E., and J. W. Davidson. 2002. Musical practice: Mother and child interactions during the first year of learning an instrument. Music Education Research 4 (1): 143-58.

- 2011. Self-regulation and mastery of musical skills. In Handbook of selfregulation oflearning and performance, ed. B. Zimmerman and D. Schunk, 234-48. New York: Routledge.

McPherson, G. E., and B. J. Zimmerman 2011. Self-regulation and musical learning: A social-cognitive perspective on developing performance skills. In MENC handbook of research on music learning. Vol. 2, Applications, ed. R. Colwell and P. Webster, 130-75. New York: Oxford University Press.

Mize, G. K. 1977. The influence of increased parental involvement in the educational process of their children. PhD diss., University of Wisconsin-Madison.

Moore, D. G., K. Burland, and J. W. Davidson. 2003. The social context of musical success: A developmental account. British Journal of Psychology 94 (4): 529-49, doi:10.1348/000712603322503088.

Moorhead, M. N. 2005. The Suzuki method: A comparative analysis of the perceptual/cognitive listening development in third grade students trained in the Suzuki, traditional, and modified Suzuki music methods. PhD diss., University of South Florida.

Parker, E. J. 2006. Piano pedagogy: A practical approach. Surrey, BC: Longbow.

Powell, M. C. 1988. Focus on Suzuki piano: Creative and effective ideas for teachers and parents. Secaucus, NJ: Summy-Birchard.

Royal Conservatory of Music. 2011. Discipline updates: The marks are in! Music Matters, March/April, accessed May 2011, http://www.rcmexaminations. org/teachinfo/mmpdffiles/MM_2011_MAR_APR.pdf.

Ryan, R. M. 1982. Control and information in the intrapersonal sphere: An extension of cognitive evaluation theory. Journal of Personality and Social Psychology 43:450-61.

Ryan, R. M., and E. L. Deci. 20ooa. Intrinsic and extrinsic motivations: Classic definitions and new directions. Contemporary Educational Psychology 25:54-67.

- 2000 b. Self-determination theory and the facilitation of intrinsic motivation, social development, and well-being. American Psychologist 55 (1): 68-78.

Ryan, R. M., and N. Weinstein. 2009. Undermining quality teaching and learning: A self-determination theory perspective on high-stakes testing. Theory and Research in Education 7:224-33. 
Salaman, W. 1994. The role of graded exams in music. British Journal of Music Education 11 (3): 209-21.

Shor, N. 1989. Very young children and piano lessons. International Journal of Music Education 13 (1): 19-30.

Sichivitsa, V. O. 2007. The influences of parents, teachers, peers and other factors on students' motivation in music. Research Studies in Music Education 29:55-68, doi:10.1177/1321103Xo7087568.

Sloboda, J. A. 1994. Do graded exams help children's musical development? Libretto (May): 8-9.

Sloboda, J. A., and J. Davidson. 1996. The young performing musician. In Musical beginnings: Origins and development of musical competence, ed. I. Deliège and J. Sloboda, 171-90. New York: Oxford University Press.

Sloboba, J. A., and M. J. A. Howe. 1991. Biographical precursors of musical excellence: An interview study. Psychology of Music 19 (1): 3-21.

Sosniak, L. A. (1985). Phases of Learning. In Developing talent in young people, ed. B. S. Bloom, 409-38. New York: Ballantine Books.

Spera, C. 2005. A review of the relationship among parenting practices, parenting styles, and adolescent school achievement. Educational Psychology Review 17 (2): 125-46.

Stein Crease, S. 2006. Music lessons: Guide your child to play a musical instrument (and enjoy it!). Chicago: Chicago Review.

Suzuki, S. 1969. Nurtured by love: A new approach to education, trans. W. Suzuki. Hicksville, NY: Exposition.

Uszler, M., S. Gordon, and S. McBride-Smith. 200o. The well-tempered keyboard teacher, and ed. Belmont, CA: Schirmer Books.

Warton, P. M. 1997. Learning about responsibility: Lessons from homework. British Journal of Educational Psychology 67:213-21.

Wheeler, L. D. 1984. The effect of parental involvement on urban elementary student achievement. EdD diss., Temple University.

Wilson, F. H. 1976. Parental involvement with their children's education on the junior high level in urban schools and its relationship to student achievement (as indicated by grade point average, rates of attendance, and citizenship average); to parental status; to distance of the home from school; and to the parent's sex. PhD diss., Michigan State University.

\section{ABSTRACT}

We examined the effects of choices parents can make regarding their child's piano lessons: age started, instruction method, taking exams, taking group lessons, sitting in on lessons, helping with home practice, giving rewards for practising. Parental choices were correlated with the following child variables regarding piano playing: autonomous motivation, interest in performance and creativity, interest in effortful practice, time spent practising, feeling of competence, and exam performance. We administered questionnaires to 173 piano students aged six to sixteen and their parents. The most beneficial predictors were: initiating lessons before age seven, sitting in on lessons, and helping with home practice. 


\section{RÉSUMÉ}

Nous avons examiné l'effet de diverses décisions que les parents peuvent prendre dans le cadre de l'apprentissage du piano de leurs enfants, par exemple au niveau de l'âge pour commencer cet apprentissage, la méthode d'enseignement, les examens, les cours de groupes, l'assistance aux cours, leur présence active lors des pratiques quotidiennes, et le fait de récompenser ces pratiques. Ces choix ont été mis en corrélation avec diverses variables se rapportant au jeu pianistique de l'enfant, c'est-à-dire à leur motivation personnelle, leur intérêt pour l'interprétation et la créativité, leur intérêt pour l'effort mis dans la pratique, le temps qui y est passé, leur sentiment d'habileté, et leur niveau de réussite aux examens. Nous avons soumis 173 élèves de piano, âgés de 6 à 16 ans, ainsi que leurs parents, à une série de questionnaires. Cette étude a permis de révéler certaines des décisions les plus bénéfiques, telles que commencer les leçons avant l'âge de 7 ans, assister aux cours, et aider aux pratiques quotidiennes.

\section{BIOGRAPHIES}

Gilles Comeau, Professor at the School of Music of the University of Ottawa, co-ordinates the piano pedagogy and the music education sectors. Dr. Comeau has been the beneficiary of many research grants, including a large grant from the Canadian Foundation for Innovation to set up a research laboratory in piano pedagogy. As head of this infrastructure, he has established partnership with many other research laboratories and research institutes and set-up different multidisciplinary research groups that study various aspects of piano learning and piano teaching: music reading, motivation, physiological aspect of piano performance, piano-playing health injuries, video-mediated learning. He has written various scholarly research papers and his research findings have received coverage in popular media outlets (television, radio and newspapers). He has authored many books, including Piano Pedagogy: A Research and Information Guide; Comparing Dalcroze, Orff and Kodály; the five volume series Histoire illustrée de la musique pour les jeunes musiciens and over 20 education kits to be used by music and arts teachers.

Veronika Huta is an Assistant Professor in the School of Psychology at the University of Ottawa. She has a PhD in clinical psychology from McGill University. Her research is on the ways in which people pursue wellbeing (e.g., hedonia, eudaimonia); how these pursuits relate to well-being outcomes, parenting predictors, and personality correlates; and the identification of major domains of well-being (e.g. subjective well-being, meaning, vitality, functioning). She teaches courses in positive psychology and graduate statistics. She is a past president of the Royal Canadian Institute, and has previously co-organized a conference on eudaimonia. 